DOC.

D101.60/2:

1754

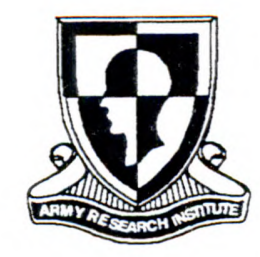

U.S. Army Research Institute

for the Behavioral and Social Sciences

Research Report 1754

\title{
Analysis of Mission-Based Scenarios for Training Soldiers and Small Unit Leaders in Virtual Environments
}

\author{
Robert J. Pleban \\ U.S. Army Research Institute \\ David E. Eakin \\ Auburn University \\ Consortium Research Fellows Program \\ Margaret S. Salter \\ U.S. Army Research Institute
}

January 2000

Approved for public release; distribution is unlimited. 